\title{
The Spirit of Buddha Nature in Japanese Zen Buddhism
}

\author{
Cheng Hong Yau \\ Department of Centre of Buddhist Studies, Faculty of Art, The University of Hong Kong, Hong Kong, China
}

Copyright @ 2015 Horizon Research Publishing All rights reserved.

\begin{abstract}
This essay will focus on the development and significance of Zen Buddhism and emergence of Zen garden architecture in Japan. In order to understand Zen Buddhism, which is a particular branch of Buddhism, this essay will provide a brief introduction to the religion of Buddhism on its origins and different movements that lead to the development of many branches of this religion worldwide at the beginning of the essay. The understanding of Buddha nature is also an essential part of learning the fundamental elements that made the religion into its shape and form today, which I will discuss deeply in the second part of my essay by using different Japanese Zen gardens as example.
\end{abstract}

Keywords Buddhism, Spirit, Buddha Nature, Japanese Zen Buddhism, Japanese Zen Garden

\section{Introduction}

Buddhism is one of the main religions that have spread into different parts of the globe, and its philosophies have heavily influenced different cultures, predominantly countries in Asia. The roots of Buddhism can be traced back to over 2500 years ago, and now it has become a religion with over 500 million followers worldwide 1 . Before Siddhartha Gautama seated under the Bodhi tree and found the truth, there were two main movements at that period, namely Brahmanism and Samanism 2. Brahmanism was about the linear development of the ancient Vedic thought, while Samanism embraced a broader spectrum of religious teachings and practices. Although their stands seem to be opposite to each other, there was one basic theoretical view accepted by both Brahmanism and Samanism, the spiritual eternalism. It referred to "The self is one things and the body another". However, there were people who believed in a radically different theoretical view, physical annihilationism, which is "The self is the same as the body" 3 . In the view of Gautama Buddha, both theories did not satisfy him because

1 N.D. (2012).The Global Religious Landscape. Retrieved from www.pewforum.org/2012/12/18/global-religious-landscape-exec/ 2 Y.KARUNADASA (2013), Early Buddhist Teaching p.13. HKU 3 Ibid., Ioc. Cit in Y.KARUNADASA (2013), Early Buddhist Teaching p.14. HKU both of the theories were either addicted to sensual pleasure or addicted to self-mortification, which were considered as unfavourable concept4. Gautama Buddja's approach was regarded as the "Middle Path". After Siddhartha Gautama attained enlightenment, he lived and taught in India sometime between $6^{\text {th }}$ and $4^{\text {th }}$ BCE. There were several key concepts inside the Buddha teaching, for instance, the Four Noble Truths, Five Aggregates, Dependent Arising, etc. Buddhism had been spread into many different branches. Initially, there were two major branches-Theravada and Mahayana. Other branches of Buddhism, such as Hinduism, Zen and more gradually developed throughout history. This essay will discuss the spirit of Buddha nature in Japanese Zen Gardens in the followings.

\section{Introduction on Buddha Nature}

Accordingly, Buddha nature is a term frequently used in Mahayana Buddhism. Buddha nature is a complex concept that cannot be defined in simple terms5, and it is the central feature of the Buddhist thought. The concept of Buddha nature conveys to us that all sentient beings possess the potential to become Buddha6, which is frequently referred into 2 terms: Tathagatagarbha and Buddhadhatu. Nevertheless, a different branch of Buddhism opine differently on this concept: some say only human beings have the potential to become Buddha, while other say the potential to become Buddha extends to all living beings, including tree and flowers. And accordingly, we can say that we are all born with Buddha Nature, only when we getting older and older, we become increasingly attached to the external world, our own experiences, and our own self-view. For one to discover his Buddha Nature, one needs to see things with an open mind in all possibilities, to accept all the possibilities and to doubt them. One must also need to control their self-view and their ego in order to see things as they really are 7. Although the term Buddha Nature is always

4 Dhammacakkappavattana Sutta: Setting the Wheel of Dhamma in Motion (SN56.11), translated from the Pali by Thanissaro Bhikkhu

5 Barbara O’Brien (n.d.) The fundamental Nature of All Beings. Retrieved from Buddhism.about.com/od/mahayanabuddhism/a/Buddha-Nature.htm

6 Lusthaus Dan, (1998), Buddhist Philosophy, Chinese: In Routledge Encyclopedia of Philosophy: Index, p.83. Taylor \& Francis

7 Om Paramapoonya, (2012) Zen Garden-History, Philosophy and How-To 
referred to Tathagatagarbha and Buddhadhatu, it is not a translation of this term, it is more likely referred to what is the essential in the human beings 8 .

\section{Discussion on Japanese Zen Buddhism}

Aforementioned, Buddhism has spread into different branches throughout the years. Buddhism has long been practiced in Japan from 1500 years ago. In Japan, Zen Buddhism is one of the most famous branches in Buddhism. Zen Buddhism is a mixture of India Mahayana Buddhism and Taoism9, and was first developed in China and was subsequently spread to Japan. In Zen Buddhism, the believers focus mainly on Buddha nature10. One of its aims is to attempt to understand the meaning of life directly without following any logic or theory, and focuses mainly on self-knowledge 11 . There are many ways for a person to learn Zen, either through meditation or physical practice. Nonetheless, what we need to know is the practice of Zen is aimed at taking the rational and intellectual mind out of the mental loop. In Japan, Buddhism was introduced to the country at $8^{\text {th }}$ century BCE, however, not until $200-300$ years later, i.e. the Kamakura Period, Zen was introduced into Japan as a separate branch of Buddhism. Throughout the following years, Zen Buddhism has spread to many other Western countries from Japan, and an increasing number of teachings and practice methods have been established and developed.

\section{Introduction on Japanese Zen Garden}

Apart from the different teachings and practice methods, different styles of art work and architecture were also created. The Japanese Zen Garden is one of the most famous architecture that was being created during the above mentioned period. Zen Garden is a garden that is built in a Zen temple, which includes rocks, sands, water and more as part of the architecture. Each material used carries a signification in Buddhism. There are many Zen Gardens in Japan, which are built during different periods. For example, in the Muromachi period, famous Zen Gardens was being built in this period., namely the gardens in Ryoan-Ji, Saiho-Ji, Tenryu-ji, Jishu-Ji and Daisen-In and Zuiho-In in Daitoku-Ji. In the later Edo period, there were other famous Zen Gardens built during that period, such as the Tofuku-Ji, Anyo-In in Taisan-Ji, Rosan-Ji, Shitenno-Ji and Myoshin-Ji.

Guide. Retrieved from Hubpages.com/hub/zen-garden-designs 8 King, Sallie B. (1991), Buddha Nature,p.5. SUNY press

9 N.D., (2002) Zen Buddhism, Retrieved from www.bbc.co.uk/religion/religions/buddhism/subdivisions/zen_1.shtml 10 Sekida Katsuki (1989), Zen training: Methods and Philosophy. Shambhala

11 N.D., (2002) Zen Buddhism, Retrieved from www.bbc.co.uk/religion/religions/buddhism/subdivisions/zen_1.shtml

\section{Representation and Symbolization of Japanese Zen Garden}

Every materials used in the Zen Garden have their own representation of certain ideas and concepts, their meanings in Buddhism will now be explained. Rock is one of the most important materials used in Zen Garden, the selection and the placement of rock is the most important part of making a Zen Garden, furthermore, specific selection and placement rules were being applied12. In a Zen Garden, rock may represent mountains, boats or living beings. Some people also believed that a rock might imply political meanings. For instance, the mountain is symbolized as the king and the rock is like the one who supports the king, and if, the mountain is without the support of rock, they will collapse easily. It implies without support, a kingship will fall very soon 13 .

Besides rock, sand and gravel are always used in the construction of the Zen Garden. People place them in a specific pattern, and occasionally, they treat it as a practice of concentration. Sand and gravel always represent mountains or some natural earth element, such as islands, rivers, etc. Traditionally, a Zen Garden was not leisure purpose (e.g. picnics). It was a place for the Zen monks to train their minds, to practice and to meditate. They think that merely reading the sutras or scriptures is insufficient and ineffective to learn and to attain enlightenment. They believe one must go through a long period of meditation and physical activities in order to attain enlightenment. Consequently, sand raking in a Zen Garden is not a way to match our aesthetic standards, but rather a method to train the monk's mentality and their thought. We can regard this as also a kind of meditation 14.

\section{Relationship between Japanese Zen Buddhism and Japanese Zen Garden}

Besides the above representation, there are more complex ways for how a Zen Garden can represent Zen. According to Tam (2011), Buddha nature is the original intrinsic nature of everything which can be understood as the embracing cause of all things 15. Take an example, the pool of Ah in Byodo-in temple of $\mathrm{Hji}$, it carries the meaning of "non-arising" and represents the 'reflections'. They means the image reflected by the pool is not owned by the pool, rather, the pool is like a TV screen reflecting the world, even though the reflection image is not real. Without the pool, however, reflections cannot appear. The reflection is the original nature of the pool, which resembles the concept from Buddha nature of how a human being should be represented, and such

12 Michael Baridon, (1998), Les Jardins, p. 485-490. R. Laffont

13 Michael Baridon, (1998), Les Jardins, p. 492. R. Laffont

14 Om Paramapoonya, (2012) Zen Garden-History, Philosophy and How-To Guide. Retrieved from

Hubpages.com/hub/zen-garden-designs

15 Tam S W (2011). Natrual Appearances, Natural Liberation, p.38-39. Sumeru 
mechanism is how we see the world16.

As I have mentioned, besides the pool I mentioned above, the rock and the sand actually have their own special pattern in the Zen Gardens. Buddha nature in Japanese Zen Gardens can actually be understood on three levels, they are phenomenal level, mental level and realization level. Now, I am going to illustrate how the design and the pattern represent the Buddha nature in these three levels.

For the phenomenal level, it represents the Buddha concept of impermanent. According to Buddhism, nothing in this world is permanent, everything is ever changing, and this is also the reason why people have dukkha. In the Zen Garden at Ryoanji Temple of Kyoto, there are 15 rocks but one cannot see them all represent together at any point in the garden. This is regarded as good architecture as it carries a very good implication: the rocks represent an incomplete composition while the sands represent the impermanent as they are ever changing. This garden has the symbolization of "Incomplete, impermanent and imperfect", all the rocks are completely there, just like the conventional world, but our conventional eye cannot perceive it. The implication of the constantly changing sand is the sense of vitality. The pattern and the placing of the rock and moss show the imperfectness between them 17. The design of this garden has represented the original intrinsic nature of things, impermanent and imperfect. It is for everyone to discover their Buddha nature and to perfect themselves.

For the mental level, it is about our mentality, consciousness and mediation. The Kenninji Temple in Kyoto, founded by a Zen monk call Abbot Eisai (1141-1215) at 1202 (who was also the founder of Japanese Zen Buddhism), is a popular site for Zen monks to practice in. Besides only learning on Zen, they also study Tendai and Shingon sects. The Court of Sound of Tides in the temple was known as the most famous court to represent this level. The design of the Court of Sound of Tides is very similar to the traditional court, the view is peaceful and empty, and the Zen monks will do mediation in this court. By walking through or sitting in this court, one's consciousness can sense the change of seasons. They can feel the sound of nature, such as the wind, the rain, the snow, etc, and also the voice of silence. By having a peaceful and insightful meditation, one can experience the sense of cognizance on the base of emptiness 18 and realize one's emptiness and omnipresent vitality inside him, which are also the original intrinsic nature of a living beings, i.e. the Buddha nature.

For the realization level, one's realization stage and the

16 Wong Wah Sang, (N.D.) Seeing Buddha Nature in Japanese Zen Gardens.p.5. The University of Hong Kong. Retrieved from http://moodle.hku.hk/pluginfile.php/801812/mod_resource/content/1/Seein g\%20Buddha\%20Nature\%20in\%20Japanese\%20Zen\%20Gardens.pdf

17 Wong Wah Sang, (N.D.) Seeing Buddha Nature in Japanese Zen Gardens.p.7. The University of Hong Kong. Retrieved from http://moodle.hku.hk/pluginfile.php/801812/mod resource/content/1/Seein g\%20Buddha\%20Nature\%20in\%20Japanese\%20Zen\%20Gardens.pdf

18 Wong Wah Sang, (N.D.) Seeing Buddha Nature in Japanese Zen Gardens.p.8. The University of Hong Kong. Retrieved from http://moodle.hku.hk/pluginfile.php/801812/mod resource/content/1/Seein g\%20Buddha\%20Nature\%20in\%20Japanese\%20Zen\%20Gardens.pdf process of life are the focus. The other Zen Garden in Kennin-ji is a perfect example. It is a garden full of white sand on the ground, and there are three objects in the garden. They are a square well covered by a square bamboo cover, a circular patch of moss with a piece of stone on the edge and a tree that with Y-shaped branches corresponding to the triangle with three sides in the middle19. This design of the garden represents the inner self-realization of wisdom and life, the designer used the bamboo cover as the representation of life, the moss as gathering life in limitation and the tree as the 'growth'. A three step sequence is therefore represented. For the tree to grow, water is an essential element required for such growth to occur, however, we cannot see any water in the garden. It is because the water is covered by the square bamboo in the underground, similar to a person's Buddha nature, it is the basis for one to live and to grow but one cannot see it. Besides the whole picture, each of the three objects also has their own symbolization. The sand on the ground is the ground purification which aims at clearing away our literal meaning and conventional conceptuality. Moss grows on water, but is limited by the rock, symbolizing the limitation and criteria one will face. The growth of the tree represents it emancipates from the boundaries of life 20 .

\section{Self Reflection}

In my opinion, these three levels play a very important role in Zen Buddhism as they represent the Tantric teaching of the three sequential natural liberations, for one to attain the highest knowledge, i.e. Nibbana, one need to be liberated from mind (mental), phenomena and equanimity (realization). Also, the above mentioned Zen Garden also plays a vital part as it is very unique in nature. Moreover, special architectures that symbolize the three levels help people to know and understand more about Zen Buddhism.

\section{Conclusions}

To conclude, Zen monks believe that by symbolizing through different materials, they are creating a miniature image of the world, which can help to remind themselves about their own deepest nature21 - the Buddha Nature. Bear in mind that, however, all representation and symbolization are assigned by human beings, we can say that the artifacts in the architecture may not possess any special value.

19 Wong Wah Sang, (N.D.) Seeing Buddha Nature in Japanese Zen Gardens.p.9. The University of Hong Kong. Retrieved from http://moodle.hku.hk/pluginfile.php/801812/mod_resource/content/1/Seein g\%20Buddha\%20Nature\%20in\%20Japanese\%20Zen\%20Gardens.pdf

20 Wong Wah Sang, (N.D.) Seeing Buddha Nature in Japanese Zen Gardens.p.10. The University of Hong Kong. Retrieved from http://moodle.hku.hk/pluginfile.php/801812/mod_resource/content /1/Seeing\%20Buddha\%20Nature\%20in\%20Japanese\%20Zen\%20 Gardens.pdf

21 Om Paramapoonya, (2012) Zen Garden-History, Philosophy and How-To Guide. Retrieved from Hubpages.com/hub/zen-garden-designs 
Regardless of such suggestion, all the Zen temples and gardens in Japan are beautiful in their own way and have a unique architecture. They have a very important role in the history of the Zen Buddhism. They also have benefitted people they provide a good location for people to learn and practice and know more about themselves and also the world, to discover their Buddha nature and to attain the highest knowledge.

\section{REFERENCES}

[1] N.D., (2012). The Global Religious Landscape. Retrieved from

www.pewforum.org/2012/12/18/global-Religious-Landscape -exec/

[2] Y.KARUNADASA (2013), Early Buddhist Teaching p.13. HKU

[3] Ibid., Ioc. Cit in Y.KARUNADASA (2013), Early Buddhist Teaching p.14. HKU

[4] Dhammacakkappavattana Sutta: Setting the Wheel of Dhamma in Motion (SN56.11), translated from the Pali by Thanissaro Bhikkhu

[5] Barbara O’Brien (n.d.) The fundamental Nature of All Beings. Retrieved from

http://buddhism.about.com/od/mahayanabuddhism/a/Buddha -Nature.htm

[6] Lusthaus Dan, (1998), Buddhist Philosophy, Chinese: In Routledge Encyclopedia of Philosophy: Index, p.83. Taylor \& Francis

[7] Om Paramapoonya, (2012) Zen Garden-History, Philosophy and How-To Guide. Retrieved from Hubpages.com/hub/zen-garden-designs

[8] King, Sallie B. (1991), Buddha Nature,p.5. SUNY press

[9] N.D. (2002). Zen Buddhism. Retrieved from www.bbc.co.uk/religion/religions/buddhism/subdivisions/ze n_1.shtml

[10] Sekida Katsuki (1989), Zen training: Methods and Philosophy. Shambhala
[11] N.D. (2002). Zen Buddhism. Retrieved from www.bbc.co.uk/religion/religions/buddhism/subdivisions/ze n_1.shtml

[12] Michael Baridon, (1998), Les Jardins, p. 485-490. R. Laffont

[13] Michael Baridon, (1998), Les Jardins, p. 492. R. Laffont

[14] Om Paramapoonya, (2012) Zen Garden-History, Philosophy and How-To Guide. Retrieved from Hubpages.com/hub/zen-garden-designs

[15] Tam S W (2011). Natrual Appearances, Natural Liberation, p.38-39. Sumeru

[16] Wong Wah Sang, (N.D.) Seeing Buddha Nature in Japanese Zen Gardens.p.5. The University of Hong Kong. Retrieved from http://moodle.hku.hk/pluginfile.php/801812/mod_resource/c ontent/1/Seeing\%20Buddha\%20Nature\%20in\%20Japanese \%20Zen\%20Gardens.pdf

[17] Wong Wah Sang, (N.D.) Seeing Buddha Nature in Japanese Zen Gardens.p.7. The University of Hong Kong. Retrieved from

http://moodle.hku.hk/pluginfile.php/801812/mod_resource/c ontent/1/Seeing\%20Buddha\%20Nature\%20in\%20Japanese \%20Zen\%20Gardens.pdf

[18] Wong Wah Sang, (N.D.) Seeing Buddha Nature in Japanese Zen Gardens.p.8. The University of Hong Kong. Retrieved from

http://moodle.hku.hk/pluginfile.php/801812/mod_resource/c ontent/1/Seeing\%20Buddha\%20Nature\%20in\%20Japanese \%20Zen\%20Gardens.pdf

[19] Wong Wah Sang, (N.D.) Seeing Buddha Nature in Japanese Zen Gardens.p.9. The University of Hong Kong. Retrieved from http://moodle.hku.hk/pluginfile.php/801812/mod_resource/c ontent/1/Seeing\%20Buddha\%20Nature\%20in\%20Japanese \%20Zen\%20Gardens.pdf

[20] Wong Wah Sang, (N.D.) Seeing Buddha Nature in Japanese Zen Gardens.p.10. The University of Hong Kong. Retrieved from

http://moodle.hku.hk/pluginfile.php/801812/mod_resource/c ontent/1/Seeing\%20Buddha\%20Nature\%20in\%20Japanese \%20Zen\%20Gardens.pdf

[21] Om Paramapoonya, (2012) Zen Garden-History, Philosophy and How-To Guide. Retrieved from Hubpages.com/hub/zen-garden-designs 